\title{
競合型ニューラルネットワークによる土地被覆分類法
}

\section{Land Cover Mapping Method Using a Competitive Neural Network}

\author{
伊藤陽介*，大松 繁** \\ Yosuke ITO, Sigeru OMATU
}

\begin{abstract}
In this paper, we propose a method to apply a competitive neural network to land cover mapping of remote sensing data. This neural network is trained by the Learning Vector Quantization (LVQ) method. For the neural network, several weight vectors of neurons in the competitive layer represent a category. We employ LVQ1 and OLVQ1 in learning algorithms of LVQ. OLVQ1 is introduced in order to obtain high speed convergence compared with LVQ1. The three types of pattern distance functions and number of neurons are considered to find an optimal LVQ method. To evaluate the classification accuracy, the LVQ1 and OLVQ1, Maximum Likelihood Method, Back Propagation Method (3 layered neural network) and Nearest Neighbor method are considered. We classify LANDSAT TM data using TR1 or TR2 type training data where TR1 includes the same number of training data for each category, and TR2 is produced by picking up pixels on a grid in a certain processing area. As a result of this experiment, the OLVQ1 using the Mahalanobis' generalized distance and TR2 outperform the other methods with respect to overall accuracy despite a very small number of neurons, for example 24. The LVQ1 and OLVQ1 using TR1 produce better classification results regarding with average accuracy compared to the other methods. This method produces excellent classification images which are more realistic and noiseless compared with the conventional methods.
\end{abstract}

\section{1.はじめに}

人工衛星を利用したリモートセンシングは，地表面 からの反射光のスペクトル分解に基づいた高品位な観 測データを広範囲にわたる領域で，同時にかつ周期的 に測定可能であるため，環境モニタリングや都市計画 の基礎資料を作成するための重要な手段となりつつあ る。それらを実現するために，リモートセンシング画 像へ土地被覆分類法を適用し，観測時における地上も しくは海洋表面に関する被覆情報を抽出する研究が報 告されている。しかし，地上約 $900 \mathrm{Km} の$ 上空から得ら れた人工衛星による観測データには，パスラディアン スや各種測定機器のノイズなどを含み，スキャ十の有 する瞬時視野角よりも小さい領域に，複数のカテゴ

* 高松工業高等専門学校 761 高松市勅使町 355

$* *$ 大阪府立大学工学部

「写真測量とリモートセンシング」VOL. 35，NO. 3， 1996
リーが混在するミクセルのため, 高度な画像解析アル ゴリズムによる土地被覆分類法が必要となっている。

一般に, 土地被覆情報は, 複数のカテゴリ一から構成 され,リモートセンシングデータの各画素域を特定のカ テゴリーに分類する土地被覆分類が, 重要となっている。

リモートセンシング画像に適用される土地被覆分類 法は, 従来から最尤法に代表される統計的な理論に基 づく手法が用いられてきだ。最尤法は，パラメトリッ クな手法であり, 各カテゴリーの確率分布を多次元正 規分布と仮定し，そのパラメータをトレーニングデー 夕の平均べクトルと分散共分散行列から推定する。各 画素は, ベイズの定理に基づき，統計的に最も確から しいカテゴリーに分類される。しかし，本来設定すべ きカテゴリーは，土地被覆情報から作成される主題図 を利用する立場から定義されるものであって，必ずし も，そのカテゴリーの確率分布が仮定されたものにな るとは限らない。したがって，最尤法を用いた場合， カテゴリーの確率分布が多次元正規性に従わないと き，それによる分類精度は，著しく低下することが考 


\section{えられる。}

以上から，カテゴリーの確率分布を仮定しなくて分 類を行うノンパラメトリックな手法が注目されてい る。この方法として, 最短距離分類法である $\mathrm{k}$-nearest neighbor 法があるが, トレーニングデー夕の選定およ びカテゴリーの汎化性, 分類に要する演算処理が多い ことなどから改善が望まれている。他方，二ューラル ネットワークは, 並列・分散・学習という特徵を有し, 人間に近いパターン認識が叮能であるという報告がな されている2)。とくに，分散記憶によって，未学習のパ ターンに対しても，それに類似しているパターンが, 同じカテゴリーに分類されるという沉化能力が期待さ れている。近年, ニューラルネットワークの高いパター ン認識能力や沉化能力を利用した土地被覆分類法が提 案されている3 ${ }^{3-9)}$ 。これらの提案手法は, 階層型二ュー ラルネットワークをバックプロパゲーション法により 学習したモデルを用いて, 分類を行っている。しかし, この学習アルゴリズムは, 最急降下法に基づき, 学䏨 回数の多さやローカルミニマムへ陥る問題がある。ま た，学習時に入力するトレーニングデータによって， 学習の収束性がクリティカルに変化し, 実用的な方法 として適用が困難となる側面もある。

一方, 二ューラルネットワークに入力したデータが, それら自身の類似度に応じて, 分類する能力を自律的 に獲得していく学習方式があり，それを実現するため のモデルとして, 競合型ニューラルネットワークがあ $3^{10)}$ このネットワークは, 層状に並んだ出力ユニット が相互に接続され，信号を伝達する形態を呈し，その 結合様式は，実際の動物の神経系において多く発見さ れている。また，これらの二ューラルネットワークの リモートセンシング画像解析への応用がなされてい

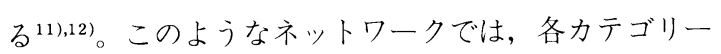
がどの出力ユニットに対応するかは，ネットワークの 初期值やトレーニングデータの入力の順序などによっ て決定される。それゆえ, 土地被覆分類法として適用 する場合には, 出力ユニットとカテゴリ一の対応を行 うことに問題があった。

Kohonen は, 競合型ニューラルネットワークの特徵 を活かしつつ，より応用しやすい形に簡略化し，特定 の入力データであるトレーニングデータによって, ニューロンの持つ重みを更新する Learning Vector Quantization 法 (以下, LVQ 法と略記する) を提案し ている ${ }^{13)-15)}$ L LVQ法によって学習したニューラル
ネットワークが, 音声認識の分野においても高い認識 能力が示されている16)。また, LVQ 法は, 光学的セン サ一に基づくリモートセンシングデー夕解析のみなら ず, SAR 画像の教師なし分類法へも適用されてい る17)。したがって, LVQ 法を用いた土地被覆分類法は, ニューラルネットワークの有するパターン認識能力と トレーニングデータ間での類似性に基づく学習という 統計的なアプローチの両方を持ち, リモートセンシン グデータへの忘用に適していると考えられる ${ }^{18)-22) 。 ~}$

本論文では, LVQ 法を土地被覆分類法として適用す る場合に必要な検討項目を, 学習アルゴリズム, 競合 層の二ューロン数,パターン距離測度関数として考え, 最尤法, 最短距離法, 階層型ニューラルネットワーク と分類精度について定量的な比較を行い有用性を検証 する。その結果を基礎として, LVQ 法による最適な土 地被覆分類法を提案する。

\section{2. 競合型ニューラルネットワークと LVQ 法}

階層型ニューラルネットワークは, 教師付き学習で あり, その学習方法は, 統計的な回㷌分析における最 小二乗法に基づいている。一方, 競合型ニューラルネッ トワークは, 教師なし学習であり, その学習方法は, クラスター分析のようにデー夕間の類似性による分類 手法に基づいている。LVQ法は, 基本的には後者に属 するが，パターン認識法としてより有効に機能させる ため, トレーニングデータにカテゴリー情報も加えた 競合学習を行っている。以下では, 競合型ニューラル ネットワークに着目し, その構造捛よび学習方法につ いて述べる。

四1は，LVQ法によって学習される競合型ニューラ

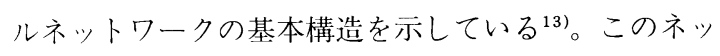
トワークは, 入力層と競合層の二層の処理要素から構 成されている。競合層の $M$ 個の処理要素であるニュー ロンは, それぞれ, $N$ 次元の入力べクトル $\mathbf{x}=$ $\left(x_{1}, \cdots, x_{N}\right)$ を受ける。入力 $x_{j}$ は，それに対応する重み 雀をかけられて, 二ューロン内部に伝達される。競合 層のニューロンiの内部状態 $u_{i}$ は, 入力ベクトル $\mathbf{x}$ とそ のニューロンの持つ重みベクトル $\mathbf{w}_{i}=\left(w_{i 1}, \cdots, w_{i N}\right)$ か ら, パターン距離測度関数 $D$ を用いて, $u_{i}=D\left(\mathbf{x}, \mathbf{w}_{i}\right)$ と なる。すべての競合層の二ューロン間で, 内部状態 $u_{i}, i=1, \cdots, M$ に基づいて競合が発生し, その結果, 勝者と なるニューロンcは， 


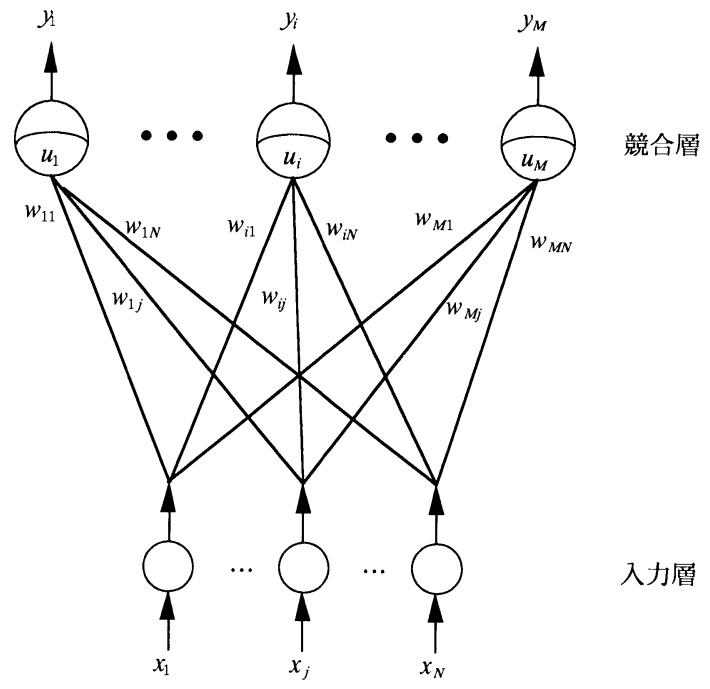

図 1 競合型ニューラルネットワークの基本構造 入カベクトル $\mathbf{x}=\left(x_{1}, \cdots, x_{N}\right)$

重みベクトル $\quad \mathbf{w}_{i}=\left(w_{i 1}, \cdots, w_{i N}\right)_{i=1}, \cdots, M$ ニューロンの内部状態 $u_{i, i=1}, \cdots, M$

出カベクトル $\mathrm{y}=\left(y_{1}, \cdots, y_{M}\right)$

$$
\boldsymbol{c}=\arg \min _{i=1, \cdots, M}\left\{u_{i}\right\}
$$

となる。その出力 $y_{c}$ は, $y_{c}=1$ となり, 他の二ューロン の出力 $y_{i}, i \neq c$ は, $y_{i}=0$ となる。

競合型ニューラルネットワークを教師付き土地被覆 分類法として適用する場合, 四2に示すような構成を考 える。入力層では, リモートセンシングデータの CCT 值を $[0,1]$ に正規化したバンド毎のデー夕を入力する。 競合層の各二ューロンは, 予如設定された L 種類の力 テゴリーのうち一つに対応付けされている。四2の競合 層において,1つのカテゴリーに対して多くの二ューロ ンを割り当てる理由は, 分類すべきカテゴリ一中には, 反射特性の異なる複数の被覆情報が含まれているため である。したがって，各カテゴリー $\omega_{k}, k=1, \cdots, L$ は，複数 のニューロンの持つ重みベクトルの集合として表現さ れる。LVQ法によって学習する場合, 競合層の二ュ一 ロンは,それぞれ，特定のカテゴリ一に対応付けされ， トレーニングデータは，入力デー夕とそれに対応する カテゴリーである。

学習の前処理段階として, 各重みベクトルの初期化 を行う。初期化方法として，一般に乱数を用いること が多いが，本論文では分類方法としての適用性の確定 度を増すため, カテゴリ一毎のトレーニングデータの

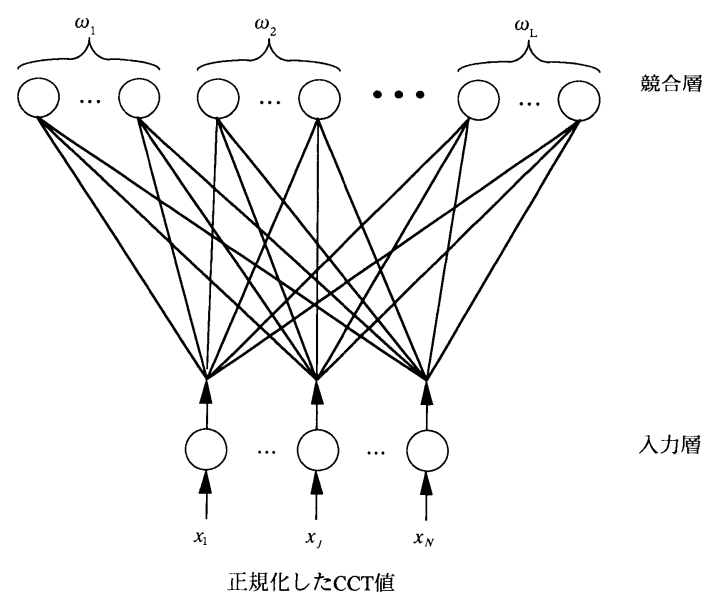

図 2 競合型ニューラルネットワークの土地被覆分類への適用構造 入カベクトル $\mathbf{x}=\left(x_{1}, \cdots, x_{N}\right)$ は $[0,1]$ に正規化した CCT 值から成る。 設定カテゴリー $\omega_{k, k=1}, \cdots, L$

平均ベクトルを, 対応する二ューロンの重みベクトル の初期值とする。

LVQ 法による学習アルゴリズムとして, Kohonen は, LVQ1, LVQ2, LVQ2.1ならびに LVQ3を提案し ている13),14)。さらに, 学習率を最適化した OLVQ1も提 案されている ${ }^{15)}$ ここれらの学習アルゴリズムは, LVQ1 を基本としたバリエーションである。リモートセンシ ングデータの土地被覆分類法へ, LVQ法を適用するこ とを考之る場合, カテゴリ一の分布状態に重なり部分 が多いことがある。その場合，学習時に複数の重みべ クトルを更新する LVQ2, LVQ2.1ならびに LVQ3は, 予期しない方向に重みべクトルを更新し，収束性に問 題を生じることがある。したがって, 本論文では, 学 習時に1つの重みべクトルのみ更新し, 他のアルゴリズ ムに比較して定数パラメータが少ないLVQ1および OLVQ1の適用について考える。

次に, LVQ1による学習アルゴリズムについて述べ る。初期化時の重みベクトルを $\mathbf{w}_{i}(0)_{, i=1, \cdots, M}$ とし, ト レーニングデータの入力回数が ルを $\mathbf{w}_{i}(t)$ とする。 $t$ 回目のトレーニングデー夕 $\mathbf{x}(t)$ が 入力された後, 競合が発生し, 勝者となるニューロン がcのとき，次のように重みベクトルを更新する。

i) $\mathbf{x}(t)$ とニューロンcの属するカテゴリーが等しい 場合

$\mathbf{w}_{c}(t+1)=\mathbf{w}_{c}(t)+\alpha(t)\left[\mathbf{x}(t)-\mathbf{w}_{c}(t)\right]$

$\mathbf{w}_{i}(t+1)=\mathbf{w}_{i}(t), i \neq c$

ii） $\mathbf{x}(t)$ とニューロンcの属するカテゴリーが異なる 
場合

$\mathbf{w}_{c}(t+1)=\mathbf{w}_{c}(t)-\alpha(t)\left[\mathbf{x}(t)-\mathbf{w}_{c}(t)\right]$

$\mathbf{w}_{i}(t+1)=\mathbf{w}_{i}(t), i \neq c$

ここで, $\alpha(t)$ は, 学習率を示し, $0<\alpha(t)<1 て ゙ あ り, ~ t$ $\rightarrow \infty の$ とき $\alpha(t) \rightarrow 0$ を満足する関数である。この学習ア ルゴリズムは, Hebbの学習則に準じた形式となって いる。すなわち、この手法は，勝者となった二ューロ ンがトレーニングデータと同じカテゴリーに属する場 合は, その重みベクトルをより適合する方向に更新し， その逆の場合は，調整方向を反対にして更新する。

LVQ1では，競合層のすべてのニューロンが同じ学 習率を持っている。線形な単調減少関数を用いる場合, 学習率 $\alpha(t)$ は,

$\alpha(t)=\alpha_{0}\left(1-\frac{t}{l_{\max }}\right)$

となる。ここで， $l_{\max }$ は，予め設定した学習回数 $l_{\max }$ で あり， $\alpha_{0}$ は，初期学習率である。 $\alpha_{0}$ は， $0<\alpha_{0}<1$ を満た す必要があるが, 実際には, $\alpha_{0}=0.3$ 程度の小さな定数 を用いる。

一方, OLVQ1による学習は, 二ューロン毎に異なる 学習率を持つ方法により，重みべクトルを更新する。 学習した重みベクトル $\mathbf{w}_{i}(t)$ は，トレーニングデータ $\mathbf{x}(t-1), \mathbf{x}(t-2), \cdots, \mathbf{x}(0)$ によって更新されている。学 習回数のいずれの段階においても, 重みべクトルの更 新に対するトレーニングデータの影響を等しくするこ

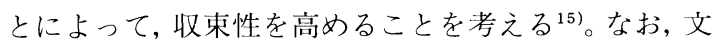
献15)では，その基本的思想しか呈示されていないの で，本論文では，付録1に示すような方法で，この学習 アルゴリズムを新たに導出する。その結果, ニューロ ンiの学習率を $\alpha_{i}(t)$ とするとき, 重みべクトルを更新 した後の学習率を，次のように更新する。

前記 i)の場合

$\alpha_{c}(t+1)=\frac{\alpha_{c}(t)}{1+\alpha_{c}(t)}$

$\alpha_{i}(t+1)=\alpha_{i}(t), i \neq c$

前記 ii) の場合

$\alpha_{c}(t+1)=\frac{\alpha_{c}(t)}{1-\alpha_{c}(t)}$

if $\alpha_{c}(t+1)>\alpha_{0}$ then $\alpha_{c}(t+1)=\alpha_{0}$

$\alpha_{i}(t+1)=\alpha_{i}(t), i \neq c$

ただし，学習率の初期化は， $\alpha_{i}(0)=\alpha_{0},{ }_{i=1, \cdots, M}$ とする。

OLVQ1による学習の終了条件として, 基本的な学習ア ルゴリズムは同じなので, LVQ1と同様に学㖬回数の みで終了を判定する。
土地被覆分類は，学習を終えて収束したニューラル ネットワークに，分類すべきリモートセンシングデー 夕を入力し, 勝者となったニューロンの属するカテゴ リーに，分類する方法で行われる。

\section{3. 分類方法と処理結果}

LVQ 法を土地被覆分類法として適用する場合, 検討 すべき項目は，1)学習アルゴリズム(LVQ1, OLVQ1), 2) カテゴリーを表現するための競合層のニューロン 数，3) パターン距離測度関数（ユークリッド距離, 重 み付きユークリッド距離，マハラノビス汎距離）が考 えられる。分類精度の高い最適な LVQ 法による方法 を提案するため, それぞれ, 検討項目を考慮し実験を 行い, その結果を従来手法と比較する。

\section{1 解析地域とリモートセンシングデータ}

本実験で解析される地域は, 図3に示す香川県高松市 を中心とした東西約 $19 \mathrm{Km}$, 南北約 $14 \mathrm{Km}$ の矩型領域 である。この地域は, 水域, 植生, 都市域を含み, 一 般的な土地被覆情報を有している。さらに, 分類精度 を求める際に必要となるグランドトゥルースデータ が, 容易に入手可能である理由から，この領域を解析 対象とすることにした。リートセンシングデータは, 被雲率がほぼ0\%に近い1988年4月28日に観測された， パスNo.110，ローNo.36の Landsat5号によるTM デー夕を用いる(図4)。分類対象画像の大きさは，640 ピクセル $\times 480$ ピクセルである。

土地被覆分類に用いる観測バンドとして，熱赤外バ ンドを除く6バンドを用いた場合, 特定のカテゴリーに おいて分散共分散行列が特異行列になることがあ

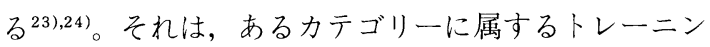
グデータにおいて, 2つ以上のバンド間で高い相関を示 すことに起因している。例えば，6バンドのトレーニン グデー夕を用いた予備実験では，「溜め池」カテゴリー の分散共分散行列に対する固有值は， $\lambda_{1}=2.39, \lambda_{2}=$ $0.68, \lambda_{3}=8.19, \lambda_{4}=23.85, \lambda_{5}=228.98, \lambda_{6}=4.03$ となり $\lambda_{2}$ が0.0に近い值を示し, 不安定な分散共分散行列と なった。他のカテゴリーも同様な傾向を示したため, 本実験では, バンド間の午長性を考慮して, 解析対象 となる画像全体に主成分分析を適用し，使用するバン ドを決定した。熱赤外バンドを除く6バンドについて， 主成分分析を行った結果を表1に示す。この結果から， 
第一主成分のみで累積寄与率は， $87.6 \%$ となり，それ

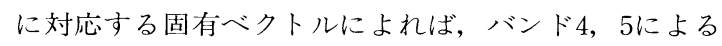
変動が大きいことがわかる。さらに，可視光領域の観 測バンドであるバンド $3 を$ 含め, 本実験では, バンド 3, 4,5 合計 3 バンドの観測デー夕を用いて土地被覆分類 の実験を行うこととする。

分類対象とするカテゴリーは, 海または川 $\left(\omega_{1}\right)$, 溜 め池 $\left(\omega_{2}\right)$, 裸地 $\left(\omega_{3}\right)$, 森林 $\left(\omega_{4}\right)$, 田畑 $\left(\omega_{5}\right)$, 密集住宅 地 $\left(\omega_{6}\right)$ の 6力テゴリーとする。分類画像上でカテゴ リーを識別するための配色は， $\omega_{1}$ : 黑, $\omega_{2}$ : 青, $\omega_{3}$ : 白, $\omega_{4}$ : 緑, $\omega_{5}$ : 黄, $\omega_{6}$ : 赤とする。通常, 海, 川, 溜め池は, まとめて水域としてカテゴリーを設定する が, 本実験では, 香川県地方の特徵的な地形である溜 め池にも着目し，単独のカテゴリーとする。

\section{2 トレーニングデータと評価データ}

本実験において，トレーニングデータは表 2 に示す 2 種類を用いる。トレーニングデータの選定の容易性を 重視したTR1, またはカテゴリーの比率に合わせてト レーニングデータを選定した TR2に対して, 分類精度 の向上が統計的に期待できる。とくに，本論文では， TR1と TR2を用いた場合の分類精度が, どの程度変化 するかを実験的に求め, 両者の比較を行う。

TR1は, 各カテゴリーについて150ピクセルを, 解析 対象画像からグランドトゥルースデー夕に基づいて選 択したデータである。TR2は, 解析対象画像の 16 ピク セル平方（地上換算約 $0.23 \mathrm{~km}^{2}$ ) の格子上のピクセル を, トレーニングデータとして, 同様に選択したデー 夕である。したがって, TR2は解析画像に含まれる力 テゴリーの被覆率とほぼ等しい割合で, トレーニング
デー夕が構成される。ただし，TR2の場合，格子上の カテゴリーの判別が困難であり, 不明確な箇所は卜 レーニングデータとして使用しない。

評価デー夕は, トレーニングデータとは別に, 解析 対象画像の 2 ピクセル平方の格子上のピクセルから選 択し, ミクセルであっても画素内に含まれる最大面積 を有すると判別されるカテゴリーを設定する。しかし， まったく同じ観測データであるのにもかかわらず，異 なるカテゴリーに設定された領域は, 両者とも評価 データとして使用しない。

本論文において, 評価対象とする土地被覆分類法は, すべて同一のトレーニングデータと評価データを用い て，分類精度の比較を行う。

\subsection{LVQ 法による土地被覆分類法}

LVQ 法を土地被覆分類法として適用する場合の検 討項目を考虑した結果, 本実験では, 表3に示すバリ エーションを考える。学習アルゴリズムである LVQ1 および OLVQ1のそれぞれに対して，パターン距離測 度関数を, 次の3通り適用する。

1）ユークリッド距離

$D_{U}\left(\mathbf{x}, \mathbf{w}_{i}\right)=\sqrt{\sum_{j=1}^{N}\left(x_{j}-w_{i j}\right)^{2}}$

2）重み付きユークリッド距離

$$
D_{W}\left(\mathbf{x}, \mathbf{w}_{i}\right)=\sqrt{\sum_{j=1}^{N} \frac{1}{\sigma_{k j}}\left(x_{j}-w_{i j}\right)^{2}}
$$

3) マハラノビス沉距離

$$
D_{M}\left(\mathbf{x}, \mathbf{w}_{i}\right)=\left(\mathbf{x}-\mathbf{w}_{i}\right) \sum_{k}^{-1}\left(\mathbf{x}-\mathbf{w}_{i}\right)^{\prime}
$$

ここで,'は転置を示す。(8), (9) 式において, 二ューロ ンiは, カテゴリー $\omega_{k}$ に対応付けられている。また,

表 1 解析対象リモートセンシングデータの主成分分析結果（熱赤外バンド７を除く）

\begin{tabular}{|c|c|c|c|c|c|c|c|}
\hline \multicolumn{2}{|c|}{ 主 成 分 } & 1 & 2 & 3 & 4 & 5 & 6 \\
\hline \multicolumn{2}{|c|}{ 固 有 值 } & 2976.67 & 337.88 & 65.51 & 10.19 & 4.94 & 0.93 \\
\hline \multicolumn{2}{|c|}{ 累積寄与率 (\%) } & 87.6 & 97.6 & 99.5 & 99.8 & 99.9 & 100.0 \\
\hline \multirow{6}{*}{$\begin{array}{l}\text { 固 } \\
\text { 有 } \\
\text { 今 } \\
\text { ク } \\
\text { ル }\end{array}$} & バンド 1 & 0.191 & -0.385 & 0.543 & 0.008 & -0.700 & -0.176 \\
\hline & バンド 2 & 0.157 & -0.177 & 0.292 & -0.120 & 0.137 & 0.909 \\
\hline & バンド 3 & 0.259 & -0.338 & 0.390 & -0.317 & 0.651 & -0.376 \\
\hline & バンド 4 & 0.445 & 0.770 & 0.417 & 0.177 & 0.035 & -0.043 \\
\hline & バンド 5 & 0.712 & -0.024 & -0.512 & -0.437 & -0.198 & 0.009 \\
\hline & バンド 7 & 0.408 & -0.334 & -0.177 & 0.814 & 0.167 & 0.003 \\
\hline
\end{tabular}
は，使用したデータを示す。 
表 2 トレーニングデータと評価データ

\begin{tabular}{|c|c|c|c|c|c|c|c|c|c|}
\hline & & カテゴリー & $\omega 1$ & $\omega 2$ & $\omega 3$ & $\omega 4$ & $\omega 5$ & $\omega 6$ & 合 計 \\
\hline \multirow{4}{*}{ 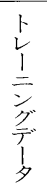 } & \multirow{2}{*}{ TR1 } & ピクセル数 & 150 & 150 & 150 & 150 & 150 & 150 & 900 \\
\hline & & 百分率 (\%) & 16.7 & 16.7 & 16.7 & 16.7 & 16.7 & 16.7 & 100.0 \\
\hline & \multirow{2}{*}{ TR2 } & ピクセル数 & 208 & 9 & 14 & 220 & 282 & 197 & 930 \\
\hline & & 百分率 (\%) & 22.4 & 1.0 & 1.5 & 23.7 & 30.3 & 21.2 & 100.0 \\
\hline \multirow{2}{*}{\multicolumn{2}{|c|}{ 評価データ }} & ピクセル数 & 14109 & 625 & 977 & 14538 & 19630 & 12705 & 62584 \\
\hline & & 百分率（\%) & 22.5 & 1.0 & 1.6 & 23.2 & 31.4 & 20.3 & 100.0 \\
\hline
\end{tabular}

$\sigma_{k j},{ }_{j=1}, \ldots,{ }_{N}$ は， $\omega_{k}$ に属するトレーニングデータの標準 偏差を示し， $\Sigma_{k}$ は分散共分散行列を示している。

統計的には， $D_{M}, D_{W}, D_{U}$ の順に高い分類精度とな ることが期待されるが，本論文では，それらの分類精 度について，定量的な比較を行う。

入力層の処理要素数 $N$ は, 入力データとして, バンド 3，4，5の正規化された CCT 值を用いることから，3と する。競合層の二ューロン数 $M$ は，設定カテゴリ一数 である6の倍数とし，各カテゴリーに対応付けされる 二ューロン数は同数とする。本実験では, 競合型二ュ一 ラルネットワークの沉化能力を調べるため, $M=$ $18,24, \cdots, 120018$ 通りの場合について分類を行う。

さらに, 各 LVQ 法について,トレーニングデータと して，TR1またはTR2を用いて，ニューラルネット ワークを学習させる。学習回数は, 予備実験の結果か ら $l_{\text {max }}=10,000$ とし, 初期学習率 $\alpha_{0}$ は, 前述した 0.3 を 用いる。ただし，学習回数は，1つのトレーニングデー 夕に対する学習を1回としている。

\section{4 比較対象とする従来の方法}

LVQ 法による分類結果を比較する従来の方法は, ハ ラメトリックな方法である最尤法 $(\mathrm{MLH})$, ノンパラ メトリックな方法である最短距離法および階層型 ニューラルネットワークを用いるバックプロパゲー ション法 $(\mathrm{BP})$ とする。最短距離法に用いるパターン 距離測度関数は, 前述した 3 種類の関数を適用し，それ ぞれ，ユークリッド最短距離法 $(\mathrm{NN}-\mathrm{U})$, 重み付き ユークリッド最短距離法 $(\mathrm{NN}-\mathrm{W})$, マハラノビス最短 距離法 $(\mathrm{NN}-\mathrm{M})$ とする。

階層型ニューラルネットワークは, 図5に示す三層か らなる多層パーセプトロンで構成されている。入力層 は， 入力データであるバンド $3 ， 4 ， 5$ に対応する3 個の ニューロンからなり, 出力層は, 6力テゴリ一のそれぞ れに対応する6個の二ューロンからなっている。隠れ層
表 3 LVQ法のバリエーション

\begin{tabular}{|c||c|c|}
\hline $\begin{array}{c}\text { パターン距 } \\
\text { 離測度関数 }\end{array}$ & $\begin{array}{c}\text { 学習アルゴリズム } \\
(\text { LVQ1) }\end{array}$ & $\begin{array}{c}\text { 学習アルゴリズム } \\
\text { (OLVQ1) }\end{array}$ \\
\hline $\mathrm{D}_{\mathrm{U}}$ & $\mathrm{LVQ1U}$ & OLVQ1U \\
\hline $\mathrm{D}_{\mathrm{W}}$ & LVQ1W & OLVQ1W \\
\hline $\mathrm{D}_{\mathrm{M}}$ & $\mathrm{LVQ} 1 \mathrm{M}$ & OLVQ1M \\
\hline
\end{tabular}

$\mathrm{D}_{\mathrm{U}}$ ：ユークリッド距離 $\mathrm{D}_{\mathrm{w}}$ ：重み付きユークリッド距離 $\mathrm{D}_{\mathrm{M}}$ : マハラノビス洲距離

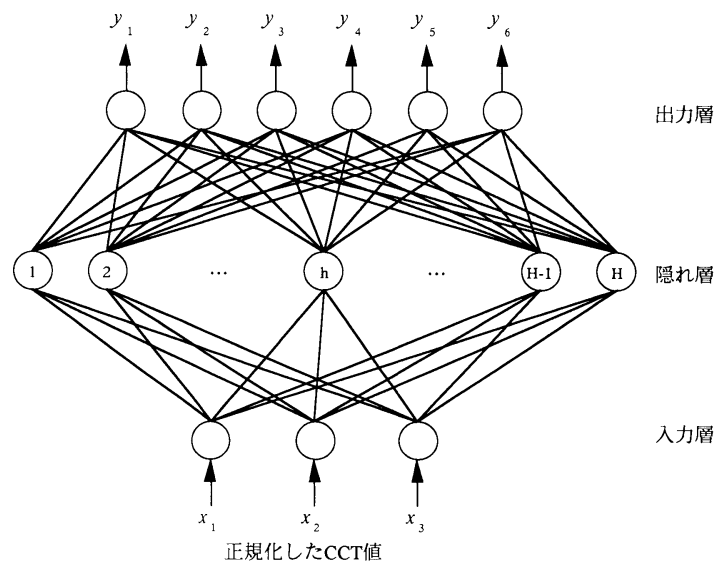

図 5 階層型ニューラルネットワークの構造

入カベクトル $\mathrm{x}=\left(x_{1}, x_{2}, x_{3}\right)$ は, (バンド 3 , バンド 4, バ ンド 5 )に対応する $[0,1]$ に正規化した CCT 值から成る。 出カベクトル $\mathrm{y}=\left(y_{1}, y_{2}, y_{3}, y_{4}, y_{5}, y_{6}\right)$

隠れ層のニューロン数 $\mathrm{H}=3 \sim 20$

$$
\begin{aligned}
\text { トレーニングデータ } \\
\omega_{1}: y=(1,0,0,0,0,0) \\
\omega_{2}: y=(0,1,0,0,0,0) \\
\text { カテゴリー } \omega_{3}: y=(0,0,1,0,0,0) \\
\omega_{4}: y=(0,0,0,1,0,0) \\
\omega_{5}: y=(0,0,0,0,1,0) \\
\omega_{6}: y=(0,0,0,0,0,1)
\end{aligned}
$$


のニューロン数 H は, 3 20個まで変化可能とする。学 習アルゴリズムはバックプロパゲーション法を用い る。トレーニングデータは, 図5に示すようなカテゴ リーに対応するニューロンの出力が1となり, 他の出力 が0となるように設定する。学習の終了判定は, トレー ニングデータとニューラルネットワークの出力の平均 二乗䛊差が 0.1 以下になるか, または学習回数が 10,000 回を超える場合とする。ただし, 学習回数は, すべて のトレーニングデータに対する学習を1回としている。 分類精度の比較条件を揃えるために, 各方法とも表 2に示すトレーニングデータ（TR1，TR2）を用いて， 分類に必要なパラメータを算出または学習し, 評価 デー夕を用いて分類精度を求める。

\section{5 分類結果と炎の評価}

表3に示す各 LVQ 法のバリエーションについて, 競 合層のニューロン数に対する総合精度および平均分類 精度を求めるために, 評価デー夕に対する分類スコア 行列 (Confusion Matrix) Aを定義する。

$$
\mathbf{A}=\left[\begin{array}{ccc}
a_{11} & \cdots & a_{1 L} \\
\vdots & \ddots & \vdots \\
a_{L 1} & \cdots & a_{L L}
\end{array}\right]
$$

ここで， $\alpha_{i j}$ は, 評価デー夕であるカテゴリーiのデー夕 が, カテゴリーjに分類されたデー夕数を示す。このと き, 総合精度 $O A(\%)$ は, 次式となる。

$$
O A=\frac{\sum_{i=1}^{L} a_{i i}}{\sum_{i=1}^{L} \sum_{j=1}^{L} a_{i j}} \times 100 \quad(\%)
$$

また, 平均分類精度 $A A(\%)$ は,

$A A=\frac{1}{L} \sum_{i=1}^{l} \frac{a_{i i}}{\sum_{j=1}^{L} a_{i j}} \times 100 \quad$ (\%)

\section{とする。}

トレーニングデータ TR1を用いて分類した結果を, 図6に示す。図6(1)は, LVQ1による分類結果を, LVQ1 U, LVQ1W，LVQ1Mについて比較したものであり， 同様に，図6(2)は, OLVQ1による分類結果を, OLVQ1 U, OLVQ1W，OLVQ1Mについて比較したものであ る。网6(3)は, 同図(1), (2)の結果から, 全体的に総 合精度が高い LVQ1W と OLVQ1M および従来方法 (NN-U，MLH，BP)の結果を比較した図である。同 様に, 図6(4)は, 平均分類精度について比較した図で ある。 BPの場合, 横軸は隠れ層のニューロン数を示
す。最短距離法の結果では, NN-U, NN-W, NN-M の総合精度が，それぞれ，76.69\%，76.45\%，76.29\% となり，ほぼ同程度の結果となったが，このうち最も 高い精度を示した NN-Uを，比較対象とした。

図6(1)，(2)の結果より，LVQ 法に用いるパターン 距離測度関数は, 統計的に明らかであるようにユーク リッド距離を用いた場合より，カテゴリーの分布を考 慮した重み付きユークリッド距離やマハラノビス距離 を用いた場合の結果の方が, 全体的に $1 \%$ 程度総合精度 が高くなっている。しかし，図6(1)の総合精度の比較 に示すように，必ずしもマハラノビス距離を用いた結 果が, 最も高い精度を示すとは限らない。この理由と しては, 分散共分散行列の特異性が関係していると考 えられる。

また, 競合層のニューロン数 $\mathrm{M}$ は, ニューラルネッ トワークの汎化能力を決定する主な要因である。 LVQ1Wの場合, M=7×6カテゴリーが, 総合精度に関 して最適となり, それ以上ニューロン数を増加させて も精度の向上はみられない。一方, OLVQ1Mの場合, $\mathrm{M}=5 \times 6$ カテゴリーが最適となり，それ以上ニューロ ン数を増加させると, 逆に分類精度が低くなる結果と なった。この要因として，トレーニングデー夕に対し て分類精度は上がるが，評価デー夕に対する精度は低 くなるという汎化能力の低下が考えられる。四6(3),

(4)におけるBPの学習状況は, 鿵れ層の二ューロン数 $\mathrm{H}=3 ， 4 ， 5,7$ におて, 収束判定で終了せず, 学習回 数が最大学習回数を超えた。それ以外の隠れ層の ニューロン数では, 収束判定条件を満足して終了した。 分類精度の比較結果は, BP において $\mathrm{H} \geqq 10$ の場合, 最

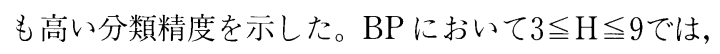
分類結果に不安定さが目立ち, この区間では LVQ 法 の方が精度が高い場合もある。MLH の結果は, $O A=$ $81.34 \%, A A=83.53 \%$ を示した。分類精度を総合的に 比較した結果, BP が最も高い精度を示した。しかし， 分類方法の実用的な忍用を考慮すると, 学習の収束が 安定している LVQ 法の方が利用しやすい。さらに, LVQ1W およびOLVQ1M では, 総合精度に関して MLH とほぼ同程度の分類精度を示したが, 平均分類 精度に関してMLHょりも高い分類結果を示し，それ らの有用性が確かめられた。

一方トレーニングデータ TR2を用いて分類した結 果を図7に示す。図7(1)〜 (4) は, 四6(1)～(4) と対応し た図である。図7(3)は，同図(1)，(2)の結果から，全 
体的に総合精度が高い LVQ1M と OLVQ1M および 従来方法 $(\mathrm{NN}-\mathrm{W}, \mathrm{MLH}, \mathrm{BP})$ の結果を比較した図 である。同様に，図7(4) は，平均分類精度について比 較した図である。最短距離法の結果では, NN-U, NN -W，NN-Mの総合精度が，それぞれ，79.93\%， 80.29\%，79.80\%となり，ほぼ同程度の結果となった が，このうち最も高い精度を示した $\mathrm{NN}-\mathrm{W}$ を比較対 象とした。

図7(1)，(2)の結果は，統計的に予想された通り，ほ ぼ，ユークリッド距離，重み付きユークリッド距離， マハラノビス汎距離を用いた順に分類精度が高くなっ ている。競合層の二ューロン数が少ない場合，マハラ ノビス沉距離の有効性が高いことを示し，他の距離測 度関数を用いた場合に比較して，1\%〜 2\%の総合精度 の向上がみられ，平均分類精度に関しては，さらに $5 \%$ 以上，精度が向上していることがある。

四7の競合層の二ューロン数に対する総合精度の変 化は，図6と同様な傾向を示し，LVQ1M の場合，M= $5 \times 6$ カテゴリー, OLVQ1Mの場合， M=4×6カテゴ リーのとき最も高い分類精度を示した。一般に,ニュー ロン数が少なくなれば，学習および分類に必要な演算 量も減少する。このように，少ない二ューロン数でカ テゴリーを表現できることは, LVQ 法の利点のひとつ である。

四7(3)，(4)におけるBPの学習状況は，隠れ層の ニューロン数のいずれの場合においても，収束判定を 満足せず, 学習回数が最大学習回数を超之た。しかし， 学習を終了した時点での平均二乗誤差は， $0.12 \sim 0.20$ となり，不十分な収束状況ではあるが，分類への適用 が可能とみなして比較した。このように，BPではト レーニングデー夕によって収束が難しい場合があり， その選択性に問題がある。さらに，図7 (3)，(4)による $\mathrm{BP}$ の結果は，分類精度の不安定さが大きく，LVQ 法 に比較して実際への応用の困難性を示している。 LVQ1M と OLVQ1M は，ほとんど同程度の分類精度 を示し, 総合精度に関して, MLH よりも $3 \%$ 以上高い 精度を有していることがわかった。しかし，平均分類 精度の場合, MLH が最も高い精度 $(82.68 \%)$ を示し た。この結果から，TR2を用いた場合，LVQ 法では， カテゴリーの出現頻度的な情報がニューロン内部に記 憶され，MLHよりも総合精度が向上したと考えられ る。一方，平均分類精度で比較した場合，逆の結果を 示し，トレーニングデータに多く含まれるカテゴリー

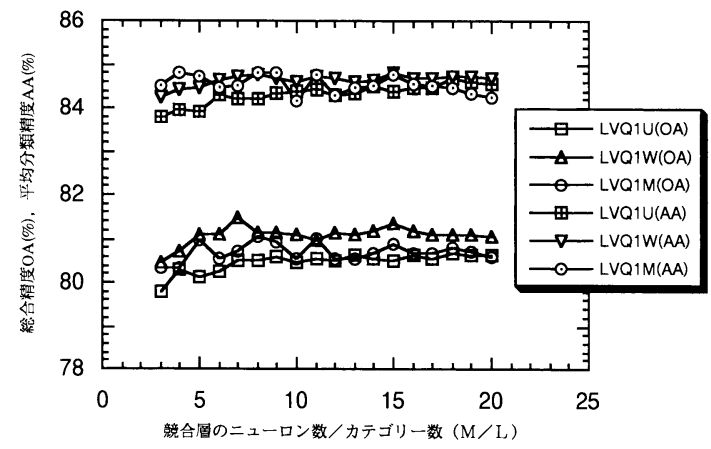

(1) トレーニングデータ(TR1)を用いたLVQ1による分類結果

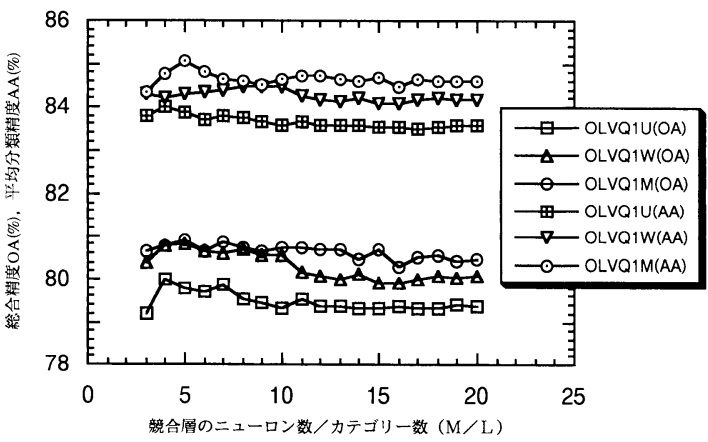

(2) トレーニングデー夕(TR1)を用いたOLVQ1による分類結果
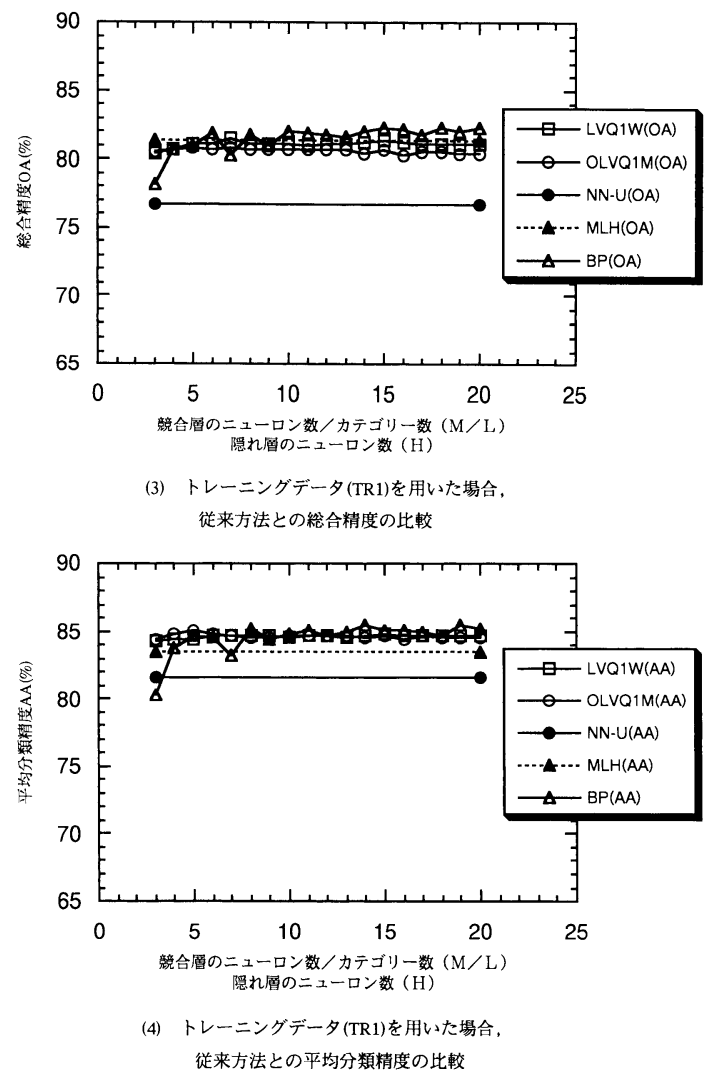

図 6 トレーニングデータ(TR1)による分類結果 


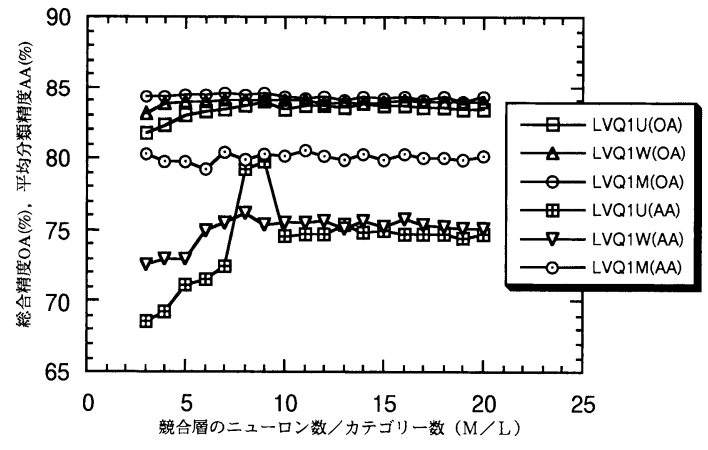

(1) トレーニングデータ(TR2)を用いたLVQ1による分類結果

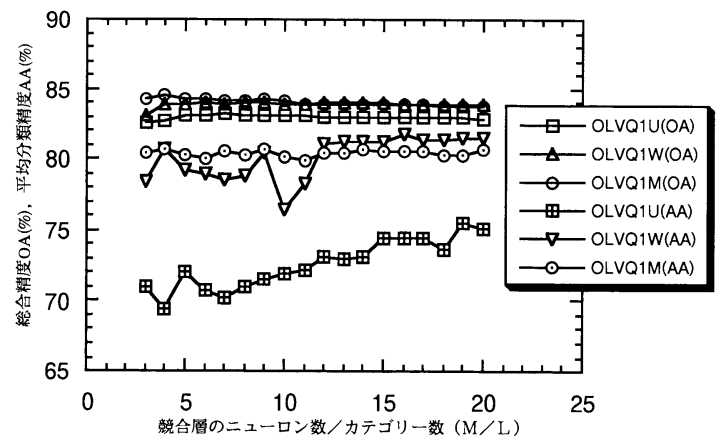

(2) トレーニングデータ(TR2)を用いたOLVQ1による分類結果
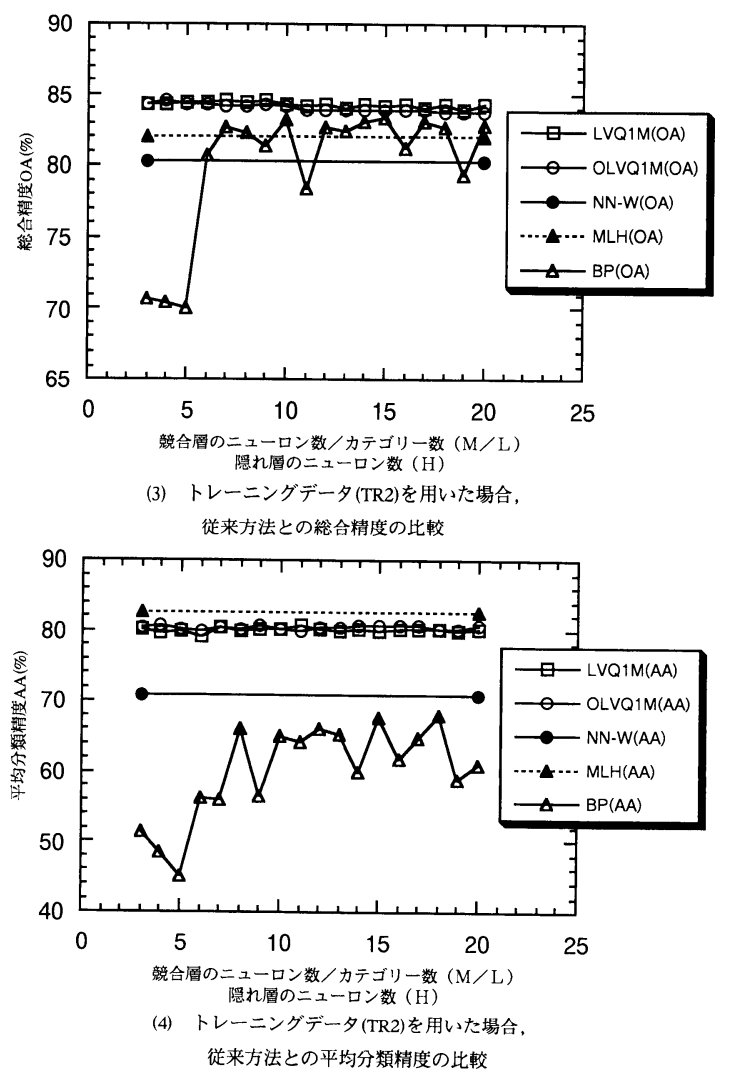

図 7 トレーニングデータ(TR2)による分類結果
の分類精度が向上した反面，少ないカテゴリーの分類 精度が低くなり，MLHに比較して，1\%程度低いこと がわかった。

以上，図6，7を総括的に比較した結果，総合精度を 分類評価基準とした場合，TR2を用いた OLVQ1M が, 最も高い精度を示し, 平均分類精度で評価した場 合，TR1を用いた OLVQ1M が，競合層のニューロン 数 $\mathrm{M}=4 \times 6$ カテゴリーで最も高い精度を示した。

次に, トレーニングデータ TR2を用いた場合の, LVQ1M と OLVQ1M の学習過程を比較して, OLVQ1 $\mathrm{M}$ の収束安定性を確認する。図8は, 入力層の処理要素 数 $\mathrm{N}=3$, 競合層のニューロン数 $\mathrm{M}=4 \times 6$ カテゴリー= 24個の競合型ニューラルネットワークをLVQ1M と OLVQ1Mによって学習した過程を示したものであ る。横軸は学習回数, 縦軸は学習時におけるトレー二 ングデータと，それを入力したときに勝者となる ニューロンの重みベクトルとの平均二乗誤差を示す。

この平均二乗誤差には, トレーニングデータと勝者 となるニューロンに属するカテゴリーが一致している かどうかという情報は含まれていない。したがって， この值が直接ニューラルネットワークの能力を示して いるのではなく，ニューラルネットワークが収束して いるかどうかを示す指標である。ニューラルネット ワークが収束した状態は，トレーニングデータがベクト 儿量子化され, 重みがカテゴリーの代表值を有した結果 平均二乗誤差が安定してきた状態であると考えられ る。

この学習結果から, OLVQ1Mによる学習が, LVQ1 $\mathrm{M}$ と比較して, 安定していることがわかる。とくに, OLVQ1M の場合, 学習回数は10,000回も必要ではな く6,000回程度で十分なことがいえる。したがって, 同

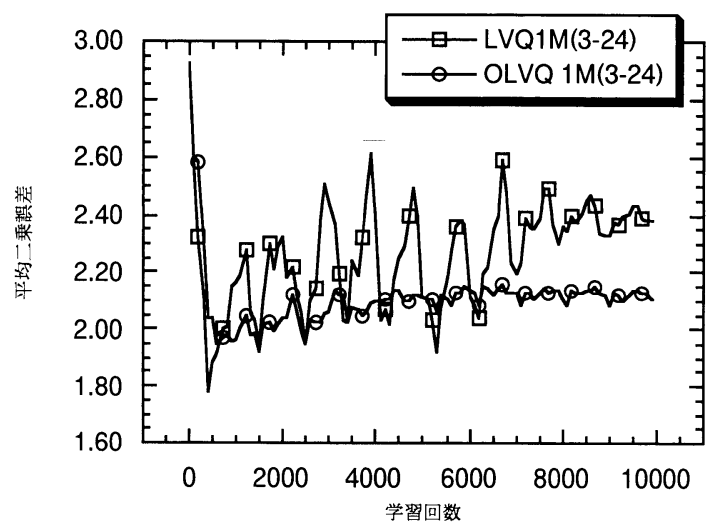

図 8 LVQ 法による学習経過 


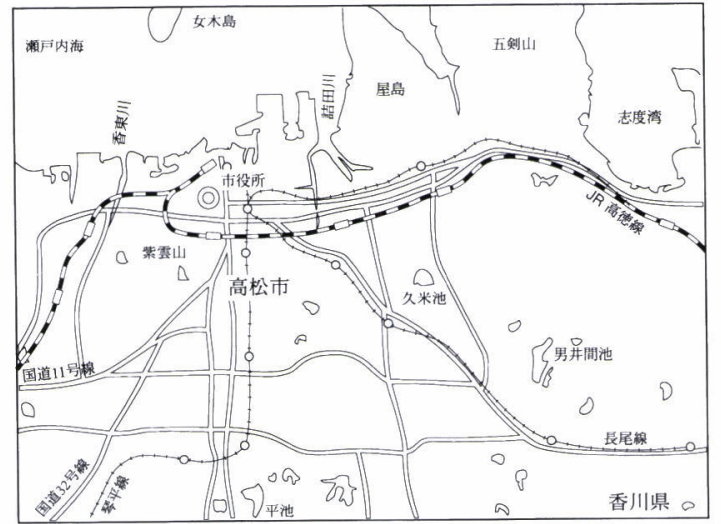

図 3 解析対象地域の概略地図

香川県高松市

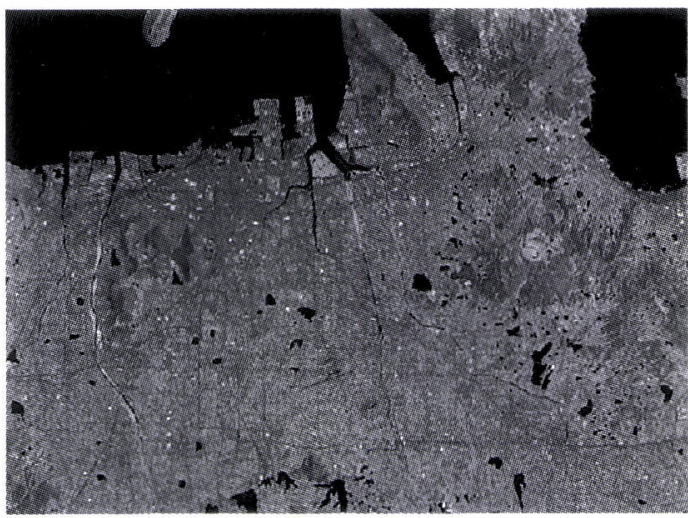

図 4 解析対象地域のリモートセンシング画像(グレイスケール)

観測衛星 Landsat 5 号

スキャナ TM

観測日 1988年4月28日

位置 パスNo.110,ローNo.36(香川県高松市)

大きさ 640 ピクセル $\times 480$ ピクセル

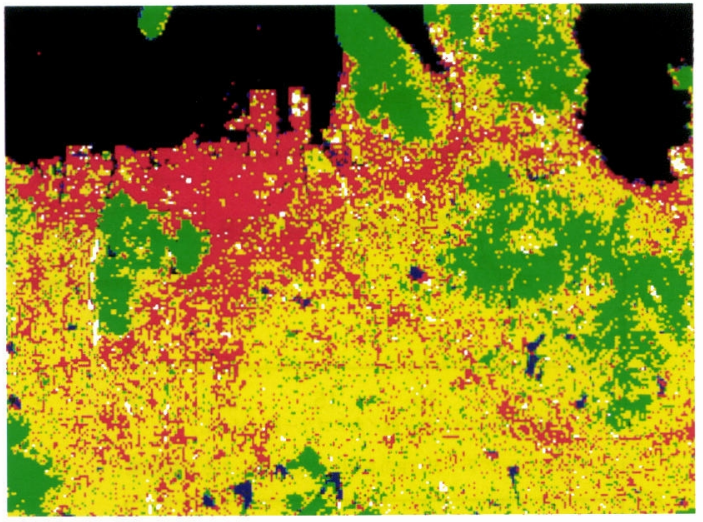

(1) NN-W による分類画像 $(\mathrm{OA}=80.29 \%)$

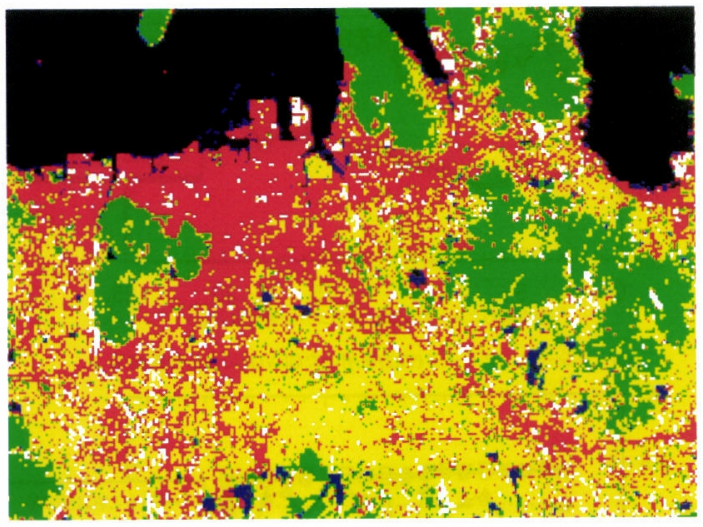

(2) $\mathrm{MLH}$ による分類画像 $(\mathrm{OA}=81.96 \%)$

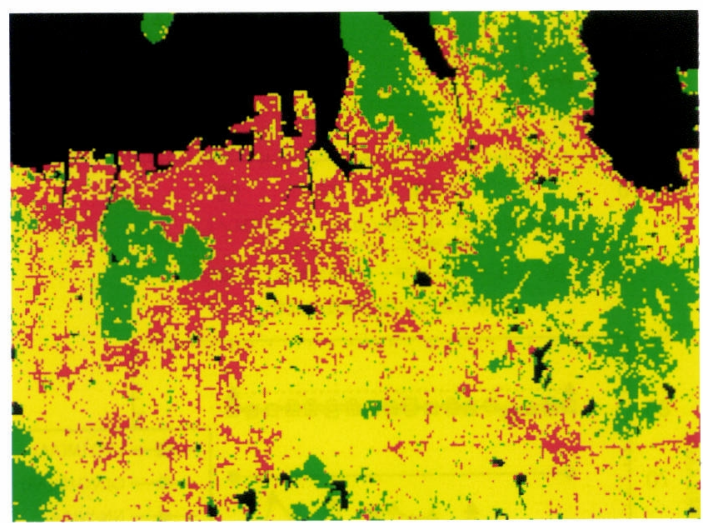

（3） BP による分類画像 $(O A=82.68 \%)$

隠れ層のニューロン数 $\mathrm{H}=7$

口海または川 ( $\omega 1) \square$ 溜め池 $(\omega 2) \square$ 裸地 $(\omega 3)$

森林 $(\omega 4) \quad \square$ 田畑 $(\omega 5) \quad \square$ 密集住宅地 $(\omega 6)$

図 9 従来方法による土地被覆分類の結果

トレーニングデータ：TR2 


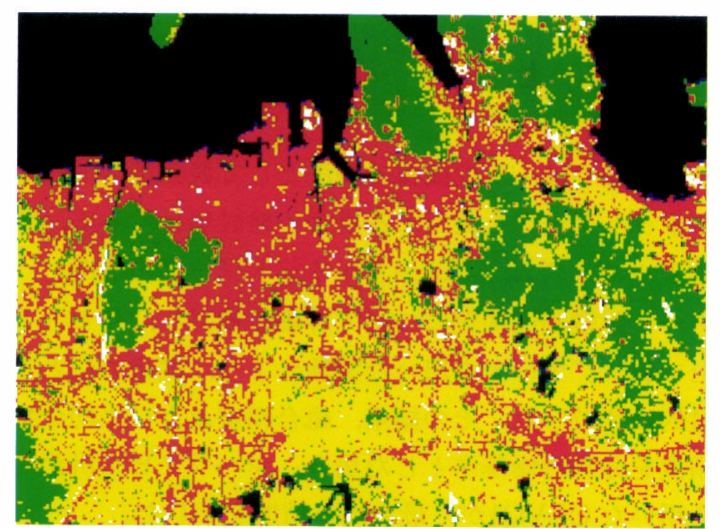

(1) LVQ1Uによる分類画像 $(O A=82.35 \%)$

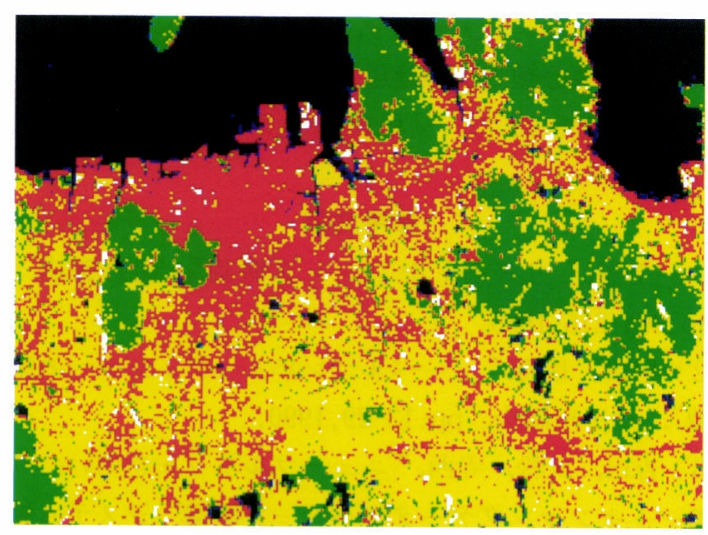

（2）LVQ1W による分類画像 $(O A=83.73 \%)$

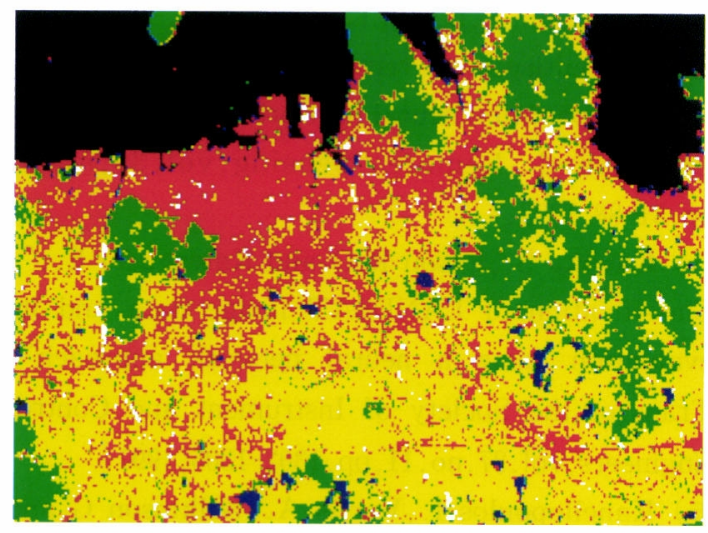

(3) LVQ1M による分類画像 $(O A=84.31 \%)$

$\square$ 海または川 ( $\omega 1) \square$ 溜め池 $(\omega 2) \square$ 裸地 $(\omega 3)$

$\square$ 森林 $(\omega 4) \quad \square$ 田畑 $(\omega 5) \quad \square$ 密集住宅地 $(\omega 6)$

図10 LVQ1による土地被覆分類の結果

$$
\begin{array}{ll}
\text { トレーニングデータ } & : \text { TR2 } \\
\text { 学習アルゴリズム } \quad: \text { LVQ1 } & \text { 競合層のニューロン数 : } 24
\end{array}
$$

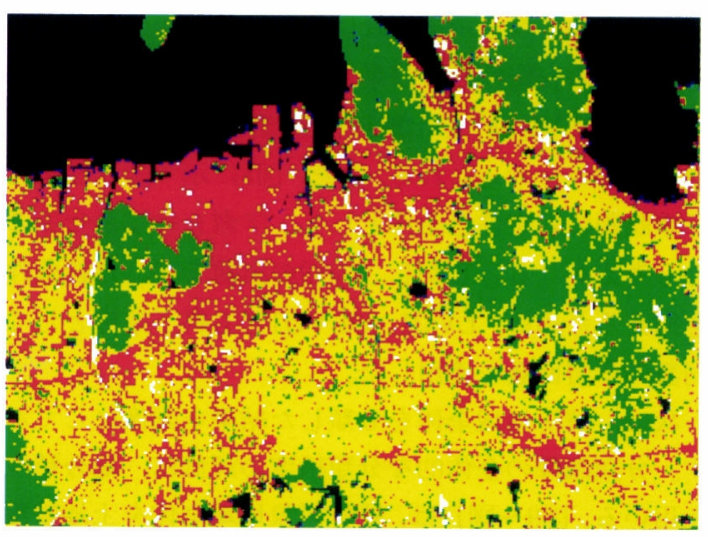

(1) OLVQ1U による分類画像 $(O A=82.66 \%)$

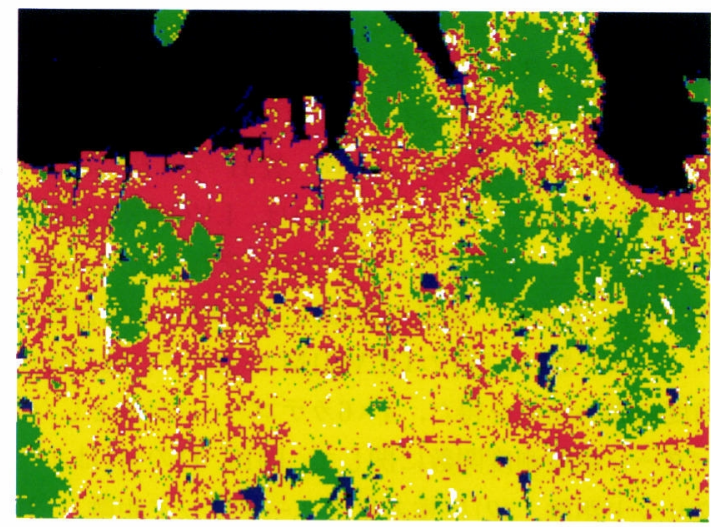

(2) OLVQ1W による分類画像 $(O A=83.87 \%)$

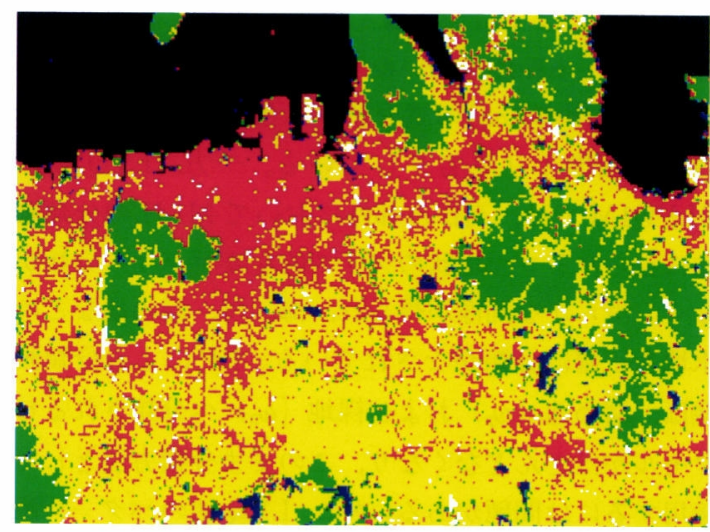

（3） OLVQ1M による分類画像 $(O A=84.51 \%)$

$\square$ 海または川 $(\omega 1) \square$ 溜め池 $(\omega 2) \square$ 裸地 $(\omega 3)$

森林 ( $\omega 4)$ ～$\square$ 田畑( $\omega 5) \quad \square$ 密集住宅地 $(\omega 6)$

図11 OLVQ1による土地被覆分類の結果

$$
\begin{array}{ll}
\text { トレーニングデータ } & \text { : TR2 } \\
\text { 学習アルゴリズム } & \text { : OLVQ1 } \\
\text { 競合層のニューロン数 }: 24
\end{array}
$$


程度の分類精度を示す場合は，学習回数が少なくてす み, 収束の安定性および高速性が優れている点から考 慮して, OLVQ1M を土地被覆分類法として, 適用する ことがよいと考えられる。また，罒8に示すような平均 二乗誤差の安定性を条件として, 学習を終了させるこ とも考えられる。しかし，今回の実験では，比較条件 を揃えるために, LVQ1, OLVQ1とも終了条件として 同数の学習回数を適用した。

次に，解析地域全体を分類した結果を画像にして示 す。分類画像の全体的な分類精度の評価は, 総合精度 を用いる。罒9 図11は, 解析対象地域全体を土地被覆 分類し，カテゴリーの識別色を用いて作成した分類画 像である。各方法に用いたトレーニングデータは, 総 合精度が高いTR2 とする。図9は，比較のため，従来方 法による分類画像を示し，同図(1)は NN-W，（2）は $\mathrm{MLH},(3)$ は隱れ層のニューロン数 $\mathrm{H}=7$ の BPによっ て作成した画像である。図10，11は，LVQ法による分 類画像を示し, 学習アルゴリズムは, それぞれ, LVQ1, OLVQ1を適用した結果である。ここで用いた競合層の ニューロン数は, 図7の OLVQ1Mにおいて, 最も総合 精度の高い結果を得た，4×6カテゴリー= 24 個とした。 パターン距離測度関数に関して, 図10，11の(1) はユー クリッド距離，（2）は重み付きユークリッド距離，（3） はマハラノビス汎距離を用いた分類画像である。

LVQ 法による分類画像を従来方法と比較すると， ユークリッド距離を用いた LVQ1U, OLVQ1Uでは, とくに, 溜め池 $\left(\omega_{2}\right)$ の誤分類が目立ち, NN-W, MLH の分類画像より見劣りしている。一方, LVQ1M, OLVQ1M では, 高松市郊外において MLH の分類画 像に見られるゴマ塩状のノイズ的なカテゴリ一分類が なく, 滑らかな画像が得られ, 海, 川, 溜め池などの 水域も正確に分類がなされている。BPによる分類画 像は, 溜め池 $\left(\omega_{2}\right)$ および裸地 $\left(\omega_{3}\right)$ 一分類されるピ クセルがほとんどなくなり，このまま分類方法として 適用するには問題がある。次に, LVQ 法のパターン距 離測度関数による分類結果について比較する。LVQ1 U, LVQ1Wによる分類画像には, 溜为池 $\left(\omega_{2}\right)$ の誤分 類が多いが, LVQ1M を用いることにより, 改善され ている。同様に, OLVQ1Uによる分類画像には, 溜め 池 $\left(\omega_{2}\right)$ の誤分類が目立つが, OLVQ1W で改善されて いる。さらに, OLVQ1W では, 高松港の防波堤付近で 海が溜め池に䛊分類されているが, OLVQ1Mの分類 画像には，それも含好䛊分類が改善されている。

\section{4. まと め}

本論文では，土地被覆分類法として競合型ニューラ ルネットワークを適用する場合の検討項目である，学 習アルゴリズム, ニューラルネットワークの構造, パ ターン距離測度関数について詳細に検討し, リモート センシングデータを用いた実験により, 従来方法と定 量的に比較した。その結果, 総合精度および平均分類 精度を分類評価基準とした場合, マハラノビス汎距離 を用いた OLVQ1が，最も高い精度を示した。

今後, LANDSAT 以外の光学的センサーによるリ モートセンシングデータや, SAR データへの本論文で の土地被覆分類方法の適用を考えていく必要がある。 (受付日1995.12.21，受理日1996.5.14)

\section{参考文献}

1) 土屋, ”リモートセンシング概論”, 朝倉書店, pp. 204-216, 1990 .

2 ) 相磯, 甘利, ”ノーベルコンピューティングへの挑 戦”, 三田出版会, pp.13-29,1990.

3 ) 吉田, 大松, 寺西, ”ニーラルネットを用いたり モートセンシングデータのパターン認識”, システム制 御情報学会論文集, vol.4,no.1,pp.11-20,1991.

4) Heermann P.D.and Khazenie N.," Classification of multispectral remote sensing data using a back-propagation neural network", IEEE Trans.on Geosci.and Remote Sensing,vol.30,no.1, pp. 81-88, 1992 .

5 ) Kawata S.,Eason R.O. and Kawaguchi E.," Classification of LANDSAT image data and its evaluation using a neural network approach", Trans. of the Society of Instrument and Control Engineers, vol.27, no.11,pp.1302-1306, 1991.

6) Kanellopoulos I., Varfis A., Wilkinson G.and Mégier J.," Land-cover discrimination in SPOT HRV imagery using an artificial neural network - a 20-class experiment", INT.J.Remote Sensing, vol.13, no.5,pp.917-924,1992.

7) Benediktsson J.A., Swain P.H.and Erosy O. K., " Neural network approaches versus statistical methods in classification of multisource remote sensing data”, IEEE Trans. on Geosci.and Remote 
Sensing, vol.28, no.4,pp.540-552, 1990.

8 ) クスハルドノ，福江，下田，坂田，”同時生起行列 に基づく空間的土地被覆分類におけるニューラルネッ トワークの利用”, 写真測量とリモートセンシング, vol.34,no.4,pp.22-35,1995.

9 ) 河邑，辻子,”多段ニューラルネットワークによる 人工衛星画像の土地被覆分類”, 写真測量とリモート七 ンシング, vol.34,no.1,pp.71-80,1995.

10）西川, 北村, ”ニューラルネットと計測制御”, 朝 倉書店, pp. 54-72,1995.

11) Hung C.C., " Competitive learning networks for unsupervised training”, INT.J.Remote Sensing, vol.14, no. 12,pp.2411-2415, 1993.

12) Yoshida T.and Omatu S.," Neural network approach to land cover mapping", IEEE Trans. on Geosci.and Remote Sensing,vol.32, no.5, pp. 1103-1109, 1994 .

13) Kohonen T., "Self-organization and associative memory", Springer-Verlag (New York), 1989.

14) Kohonen T.," Statistical pattern recognition revisited", Advanced Neural Computers, Elsevier Science Publishers B.V.(North-Holland), pp. 137-144, 1990 .

15) Kohonen T., Hynninen J., Kangas J., Laaksonen J. and Torkkola K. ," LVQ_PAK:The learning vector quantization program package version 3.1", Helsinki Univ . of Tech.Lab.of Computer and Information Science, April 7,1995.

16) Kohonen T.," The Self-Organizing Map", Proceeding of the IEEE, vol.78,no.9, pp.1464-1480,1990.

17) Hara Y.,Atkins R.G., Yueh S.H., Shin R.T. and Kong J.A.," Application of neural networks to radar image classification", IEEE Trans.on Geosci.and Remote Sensing,vol.32,no.1, pp. 100-109, 1994 .

18) Geva S. and Sitte J., " Adaptive nearest neighbor pattern classification", IEEE Trans. on Neural Networks, vol.2,no.2,pp.318-322,1991.

19）伊藤，大松，”モートセンシングデータのノンパ ラメトリック分類方法について”, 高松工業高等専門学 校研究紀要第28号, pp.23-29,1992.

20）伊藤，大松, ”学習ベクトル量子化法によるリモー
トセンシングデータの分類精度評価”, 日本リモートセ ンシング学会第13回学術講演会論文集 (広島), pp. 51-52,1992.

21）伊藤，大松，”最適化学習率 LVQによる土地被覆 分類法”, 日本リモートセンシング学会第19回学術講演 会論文集（名古屋），pp.173-174,1995.

22) Ito Y.and Omatu S., " Category classification using self-organization network",Proc. of ISNCR -94 (Kawasaki Japan),pp.537-542,1994.

23）日本リモートセンシング研究会編, ”画像の処理と 解析”, 共立出版, pp.208-211, 1981.

24）星, ”地形情報処理学”, 森北出版, pp.175-176, 1991.

付録1. OLVQ1の学習率の導出

競合の後, 勝者となったニューロンをcとするとき，重み ベクトル $\mathbf{w}_{c}(t)$ は，次のように更新される。

i） $\mathbf{x}(t)$ とニューロンcの属するカテゴリーが等しい場合

$\mathbf{w}_{c}(t+1)=\mathbf{w}_{c}(t)+\alpha_{c}(t)\left[\mathbf{x}(t)-\mathbf{w}_{c}(t)\right]$

ii） $\mathbf{x}(t)$ とニューロンcの属するカテゴリーが異なる場合

$\mathbf{w}_{c}(t+1)=\mathbf{w}_{c}(t)-\alpha_{c}(t)\left[\mathbf{x}(t)-\mathbf{w}_{c}(t)\right]$

(12) 式のとき $s(t)=+1,(13)$ 式のとき $s(t)=-1$ とすると,

まとめて $\mathbf{w}_{c}(t+1)=\mathbf{w}_{c}(t)+s(t) \alpha_{c}(t)\left[\mathbf{x}(t)-\mathbf{w}_{c}(t)\right]$ $=\left[1-s(t) \alpha_{c}(t)\right] \mathbf{w}_{c}(t)+s(t) \alpha_{c}(t) \mathbf{x}(t)$

となる。この式を $\mathbf{w}_{c}(t)$ で解くと，

$$
\mathbf{w}_{c}(t)=\frac{\mathbf{w}_{c}(t+1)-s(t) \alpha_{c}(t) \mathbf{x}(t)}{1-s(t) \alpha_{c}(t)}
$$

である。一方, $\mathbf{w}_{c}(t)$ は,

$\mathbf{w}_{c}(t)=\mathbf{w}_{c}(t-1)+s(t-1) \alpha_{c}(t-1)\left[\mathbf{x}(t-1)-\mathbf{w}_{c}(t-1)\right]$

であるから，

$$
\frac{\mathbf{w}_{c}(t+1)-s(t) \alpha_{c}(t) \mathbf{x}(t)}{1-s(t) \alpha_{c}(t)}=\mathbf{w}_{c}(t-1)+s(t-1) \alpha_{c}(t-1)\left[\mathbf{x}(t-1)-\mathbf{w}_{c}(t-1)\right]
$$

より,

$\mathbf{w}_{c}(t+1)=\left[1-s(t) \alpha_{c}(t)\right]\left[1-s(t-1) \alpha_{c}(t-1)\right] \mathbf{w}_{c}(t-1)+s(t) \alpha_{c}(t) \mathbf{x}(t)+$ $s(t-1) \alpha_{c}(t-1)\left[1-s(t) \alpha_{c}(t)\right] \mathbf{x}(t-1)$

となる。 $\mathbf{x}(t)$ と $\mathbf{x}(t-1) の$ 係数の絶対值を等しくすることに より， $\mathbf{w}_{c}(t+1)$ に及ばす $\mathbf{x}(t), \mathbf{x}(t-1), \cdots, \mathbf{x}(0) の$ 影響をす べて等しくすることができる。したがって，

$\alpha_{c}(t)=\alpha_{c}(t-1)\left[1-s(t) \alpha_{c}(t)\right]$

となればよい。 $\alpha_{c}(t)$ で解くと，

$\alpha_{c}(t)=\frac{\alpha_{c}(t-1)}{1+s(t) \alpha_{c}(t-1)}$

である。以上から，OLVQ1は，(14)式により学習率 $\alpha_{c}(t)$ を 更新する。 